The "Spinks report" on the future of biotechnology in the UK was finally published last week. Robert Walgate reports

"THERE is a clear pre-development gap in R\&D funding in Britain" Dr Alfred Spinks, chairman of a working party whose report* on UK biotechnology had just been published told a press conference last week. There is too little adventurousness, "a lack of gambling money". This is what is needed now for biotechnology in the UK, though it was clear that "one cannot transform the UK into an entrepreneurial state like California".

Dr Spink's report, prepared by the sevenman working party, says that "the present structure of public and private support for $R \& D$ is not well-suited to the development of a subject like biotechnology which, at the moment, straddles the divisions of responsibility both among government departments and among research councils and the arbitrarily defined fields of applied and fundamental research".

The recommendations and criticims in the report are substantially the same as those included in a draft version detailed in Nature on 24 January (page 324). A joint committee for biotechnology should be set up to coordinate the biotechnical work of the five research councils, and a parallel interdepartmental steering committee set up for government departments.

Research councils should double their present commitment to biotechnology to a level of at least $£ 3$ million a year, and government departments should commit some $£ 2.5$ million. The National Enterprise Board and National Research Development Corporation should consider setting up a "research-oriented biotechnology company" with $£ 2$ million a year for five years.

John Ashworth, Chief Scientist at the Cabinet Office, who coordinated the working party, said "after five years we would expect industry to come in and invest in the company. If they don't, the venture will have failed."

"People are the main problem, not money" said Ashworth. The estimated spending on a biotechnical firm had included $£ 1$ million a year overheads, plus 50 scientists at $£ 10,000$ salary plus $£ 10,000$ research expenses. The 50 people could be found without difficulty, despite the increasing recruitment to foreign firms, thought Dr Spinks. "And we should also look abroad for talent".

The report supports the expansion of centres of excellence in the subject in universities. "A minimum of 20 new teaching and research posts should be created over the next five years with a capital investment of around $£ 2$ million" for lab facilities, says the report, and careful attention should be paid to the training of an appropriate workforce.

- Professor Brian Hartley, a member of the Spinks working party, said last week that it was too late to consider setting up a firm to exploit British biotechnical talent, as recommended in the report.

Professor Hartley is a British member of Biogen, a US and Canadian-funded genetic engineering contract research body on which the UK firm, code-named 'Greenfields' by the National Enterprise Board, might be modelled. Biogen announced the cloning of interferon in the bacterium $E$. coli a few weeks ago, and completed a laboratory in Geneva last December; and recently it has been recruiting new staff.

The problem a new UK-based firm would face would be to find enough good staff," said Hartley. "A month ago they were available. Now they've joined us."

Hartley would not give precise figures. But "a few tens" have been recruited for the Geneva laboratory, to be compared with the 50 required for the UK firm.

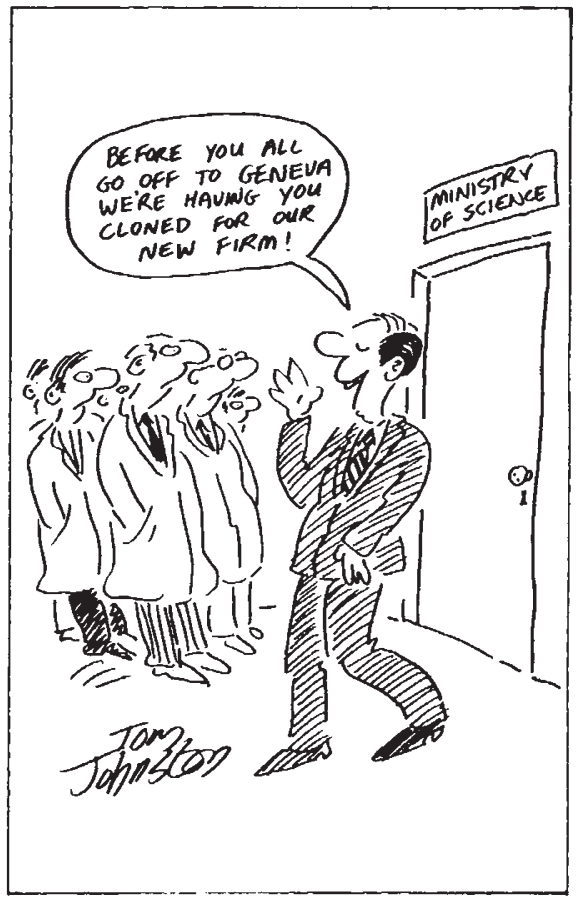

*Biotechnology, HMSO, £3

\title{
Crucial NEB decision due today
}

IF all goes according to plan, the UK National Enterprise Board (NEB) will today be taking a crucial decision on whether or not to seek ministerial approval to sink at least $£ 10$ million of public funds into British biotechnology.

The idea that the NEB should become involved in biotechnology receives impetus from last week's publication of the Spinks report which recommends that public funds be used to set up a researchorientated biotechnology company in Britain. However, the NEB were already investigating the possibility last summer. And last December, Mr Benjamin Lewin, editor of the journal Cell, was in the UK sounding out the opinion of British scientists on behalf of the NEB.

Although the details of the proposal are unclear, it is believed to favour both the establishment of a small specialist company and the funding of promising research in academic laboratories. In that way it might be possible to make the most of the proposed investment of $£ 10$ million, over a five-year period.

If the NEB decides to proceed with the British proposal, it is almost certain to have to seek approval from the Secretary of State, Sir Keith Joseph. Strictly speaking, the NEB would not need to do this because it was delegated the authority to invest up to $£ 10$ million by the Labour government which set it up in 1975. The Conservative government is less well disposed towards the concept of the NEB, (particularly because it was often used to rescue the lame ducks of British industry) and is in the process of limiting its role and reducing to $£ 5$ million the sum it can invest without ministerial approval.

Likely recipients of any funds made available by an NEB-owned company would include the Agricultural Research Council's Plant Breeding Research Institute, the Imperial Cancer Research Fund laboratory in London and such Medical Research Council (MRC) laboratories as the Cell Immunology Unit in Oxford and the Laboratory of Molecular Biology in Cambridge. Within each of these laboratories there is considerable expertise on two of the techniques which underpin the current wave of biotechnology, namely genetic engineering through recombinant DNA techniques and monoclonal antibody production from hybrid cells.

Under pressure from the Treasury to take more seriously than it sometimes has done the possibility of commercially exploiting scientific discoveries made in its laboratories, the MRC has recently reminded its senior scientific staff of their obligation to draw to the Council's attention any results of commercial potential. In particular the MRC is interested in the distribution and marketing of monoclonal antibodies derived from hybrid cells by the technique devised in 1975 by Dr Caeser Milstein and Dr George Kohler in the MRC Laboratory 